\title{
A SLAVE FAMILY IN THE ANTE BELLUM SOUTH
}

By: Loren Schweninger

Schweninger, L. "A Slave Family in the Ante-Bellum South," Journal of Negro History 60 (January 1975):29-44.

Made available courtesy of Association for the Study of African American Life and History: http://jaah.asalh.net/jaah.htm

\section{***Note: Figures may be missing from this format of the document}

Twentieth century scholars of Afro-American history have offered two basically different interpretations concerning the effect of slavery on the black family. In his famous 1932 study The Negro Family in the United States, Negro sociologist E. Franklin Frazier asserted that slavery destroyed the black family. Fundamental economic forces and material interests, he said, shattered even the toughest bonds of black familial sentiments and parental love. ${ }^{1}$ Supporting Frazier in the 1959 comparative analysis, Slavery: A Problem in American Intellectual and Institutional Life, white historian Stanley M. Elkins listed four reasons for the destruction of the black slave family: sexual exploitation, separation, miscegenation, and restrictive legal codes. "The law could permit no aspect of the slave's conjugal state to have an independent legal existence." ${ }^{2}$ In an examination of the urban South, historian Richard C. Wade likewise concluded that "For a slave, no matter where he resided, a house was never a home. Families could scarcely exist in bondage. The law recognized no marriage." ${ }^{3}$ And Daniel P. Moynihan, in his 1965 report, re-iterated that slavery had an extremely negative effect on the black family. ${ }^{4}$

Recently, three writers have put forth a far more optimistic view of the black family in bondage. Herbert Gutman, Robert Abzug and John Blassingame contend that strong family loyalties developed among slaves. Admitting the obvious institutional barriers, they argue that bondsmen used the family as a shelter against the brutalities of the Southern slave system. "Although it was weak, although it was frequently broken," Professor Blassingame writes in The Slave Commanity, a psychological study of Blacks in bondage, "the family provided an important buffer, a refuge from the rigors of slavery." ${ }^{5}$ Thus, though asking the same basic question of the

\footnotetext{
${ }^{1}$ E. Franklin Frazier, The Negro Family in the United States (Chicago: University of Chicago Press, 1939), pp. 40, 41; "The Negro Slave Family," Journal of Negro History XV (April, 1930), pp. 198-259.

${ }^{2}$ Stanley M. Elkins, Slavery: A Problem in American Institutional and Intellectual Life (Chicago: University of Chicago Press, 1959), pp. 53, 54.

${ }^{3}$ Richard C. Wade, Slavery in the Cities: The South, 1820-1860 (New York: Oxford University Press, 1964), pp. 117-121.

${ }^{4}$ Lee Rainwater and William L. Yancey, The Moynihan Report and the Politics of Controversy (Cambridge, Massachusetts: The Massachusetts Institute of Technology Press, 1967), pp. 61, 62, 414, 415.

${ }^{5}$ Herbert Gutman is working on a book length study of the black family. See: Tamara K. Hareven, editor, Anonymous Americans: Explorations in Nineteenth-Century Social History (Englewood Cliffs, N.J.: Prentice-Hall, Inc., 1971), p. 209; Robert H. Abzug, "The Black Family During Reconstruction," in Nathan I. Huggins, Martin Kilson and Daniel M. Fox, Key Issues in the Afro-American Experience (New York: Harcourt Brace Jovanovich, Inc., 1971), pp. 26-41; John W. Blassingame, The Slave Community: Plantation Life in the Ante-Bellum South (New York: Oxford University Press, 1971), chapter III.
} 
way in which the institution of slavery affected the black family, scholars have advanced two fundamentally different interpretations.

An investigation of one slave family will not end the controversy. In a limited sense it can only tell us about a family, and one that was in many respects very fortunate. ${ }^{6}$ The members of the Thomas-Rapier slave family received an education; achieved a degree of economic independence; and eventually became free or at least "quasi-free." Moreover, they belonged to extremely permissive and beneficent masters. They lived in an urban environment (as did only $10 \%$ of the South's slave population), and hired out, though it was against the law. But, like many other Blacks in the ante bellum South, they too suffered the pains of separation (living in Alabama, Tennessee, and Canada); sexual exploitation (the slave mother bore three sons by three different white men); and the legal denial of the slave family. Yet, in spite of these institutional barriers or perhaps because of them, the members of the Thomas-Rapier family maintained their integrity. Indeed, as seen in a rare collection of slave letters, notes, and autobiographical reminiscences, they preserved a cohesive family unit for three generations. In a larger sense, then, an investigation of one slave family can perhaps shed some light on the family experiences of many slaves in the ante bellum South.

Born in Albemarle County, Virginia, about 1790, the black slave, Sally, grew up on the 1500acre tobacco plantation of Charles S. Thomas, a friend and neighbor of Thomas Jefferson. ${ }^{7}$ At a young age she was sent to the fields. Working from sun-up to sundown, season to season, and year to year, she (along with forty-one other slaves on the "big gang"), prepared beds, planted seeds, transplanted shoots, "wormed and topped" young plants, hung, and then stripped, sorted and bundled the final product. When she was about eighteen, Sally suffered (or accepted) the sexual advances of a white man, (probably John Thomas, the owner's eldest son); and in September 1808, she gave birth to a mulatto boy, John. Some years later she gave birth to a second mulatto child, Henry. ${ }^{8}$ As Virginia law required that progeny take the status of the mother, both children were born in bondage, but as part of the Thomas Trust Estate, they were protected against sale or separation. ${ }^{9}$ Consequently, when one of the heirs of the estate (again probably John) joined the westward movement of slaveholders across the Appalachians into the

\footnotetext{
${ }^{6}$ It is not the purpose of this paper to enter the contemporary sociological debate on the origins of the "black matriarchy." As it happened, the central figure in this slave family was a woman. All three of her slave children, however, became dominant fathers, maintaining their marriages for twenty-six, forty-two, and thirty years respectively. In addition, it is not the purpose of this essay to differentiate between the family attitudes of the mother, who remained in bondage, and her children, who eventually gained their freedom. Their family attitudes were for the most part the same.

7 "The Autobiographical Reminiscences of James P. Thomas," Moorland-Spingarn Collection, Howard University, Washington, D.C., [1911], p. 1; hereafter "Thomas Autobiography." In the original manuscript many of the pages are out of place and unnumbered. Thus the page numbers cited are only approximate; Albemarle County Probate Records, Deed Books, Book XXXH (January 2, 1835), p. 89; ibld., Book VI (July 14, 1814), p. 26; ibid., Book IX (November 17, 1825), p. 260; The Genealogy of a Slave Family.

8 "Thomas Autobiography," pp. 2-7; U.S. Census Office, Sixth Census of the United States, "Population Schedules for Lauderdale County, Alabama," Vol. IV, 1840, p. 104.

${ }^{9}$ Winthrop Jordan, White Over Black: American Attitudes Toward the Negro, 1550-1812 (Chapel Hill: University of North Carolina Press, 1968), p. 76; Albemarle County Probate Records, Deed Books, Book XXXH (January 2, 1835), pp. 89, 90.
} 
Cumberland river valley about 1818, Sally, John and Henry were transported to the fast growing town of Nashville, Tennessee. ${ }^{10}$

The city offered many opportunities. With the master's permission, Sally hired out as a cleaning lady, a practice common among urban slaves, and secured an agreement to retain a portion of her earnings. She then rented a two-story frame house on the corner of Deaderick and Cherry Streets in the central business district. Converting the front room into a laundry, and manufacturing her own soap (blending fats, oils, alkali and salt in a small vat in the front room), she established a business of cleaning clothes. She soon built up a thriving trade. ${ }^{11}$ At the same time Sally arranged for her eldest son, John, to hire out as a waiter and poll boy to river barge Captain Richard Rapier, ${ }^{12}$ who was plying the Cumberland-Tennessee-Mississippi river trade, between Nashville, Florence (Alabama), and New Orleans; ${ }^{13}$ and arranged for Henry to hire out as an errand boy to various "white gentlemen" around Nashville. Part of their earnings, along with her own, she saved in a tea cannister, which she hid in the loft, hoping someday to be able to purchase "free papers" for the children. "However, that might cost as much as \$2000!" Undeterred, she conscientiously set aside part of her earnings every month, and by early 1826 , she had saved over $\$ 300$. $^{14}$

Though thirty-six years old, Sally was still an attractive woman. In October 1827, in the house on Deaderick Street she gave birth to a third mulatto son, James. ${ }^{15}$ The father was the famous ante bellum Judge John Catron, but according to the state law, which, like the law in Virginia, assigned progeny the status of the mother, James was born in bondage. "Now my own father presided over the supreme court of Tennessee [and served as a justice on the United States Supreme Court]," James later recalled, "[but] he had no time to give me a thought. He gave me 25 cents once, [and] if I [were] correctly informed, that is all he ever did for me." ${ }^{16}$ With three children, John nineteen, Henry about sixteen, and James, Sally despaired that she might not be able to save enough to free her family.

But her despair soon turned to joy. She received word in 1829 that her eldest son had been emancipated. "I bequeath one thousand dollars to my executors for the purpose of purchasing the freedom of the mulatto boy, John, who now waits on me, and belongs to the Estate of Thomas," Richard Rapier stipulated in his will, and the Alabama General Assembly, the only legal

10 "Thomas Autobiography," pp. 3-6.

${ }^{11}$ Ibid.; The Nashville Business Directory (Nashville: Printed by John P. Campbell, 1855), passim; "Miscellaneous Notes of James P. Thomas," Moorland-Spingarn Collection, Howard University, Washington, D.C., n.p.

12 "Richard Rapier, described as "a large fleshy man weighing over 200 pounds," settled in Nashville about 1799. Soon he was transporting large quantities of tobacco to New Orleans and returning with sugar, teas and coffee. In 1806 he formed a "copartnership" with Lemuel T. Turner and James Jackson.

${ }^{13}$ Davidson County Probate Records, Minutes, Vol. C. (July 1801), p. 405; The Tennessee Gazette and Metro District Advertiser Repository, March 29, 1898; The Clarion, September 27, 1808; The Imperial Review and Cumberland Repository, May 5, 1808; The Democratic Clarion and Tennessee Gazette, May 19, 1812, May 31, 1814.

14 "Thomas Autobiography," chapter 1; "Miscellaneous Notes of James P. Thomas," Moorland-Spingarn Collection, Howard University, Washington, D.C., n.p. (See page 33)

15 "Thomas Autobiography," p. 7.

16 Ibid., chapter 1; Acts Passed at the First and Second Session of the Nineteenth General Assembly of the State of Tennessee (Nashville: Allen Hall and A. S. Heiskel, Printers to the State, 1832), pp. 167-170. 
emancipator of slaves in the state, passed a law freeing "a certain male slave by the name of John H. Rapier." ${ }^{17}$ Then, she saw an opportunity to free Henry. With the final

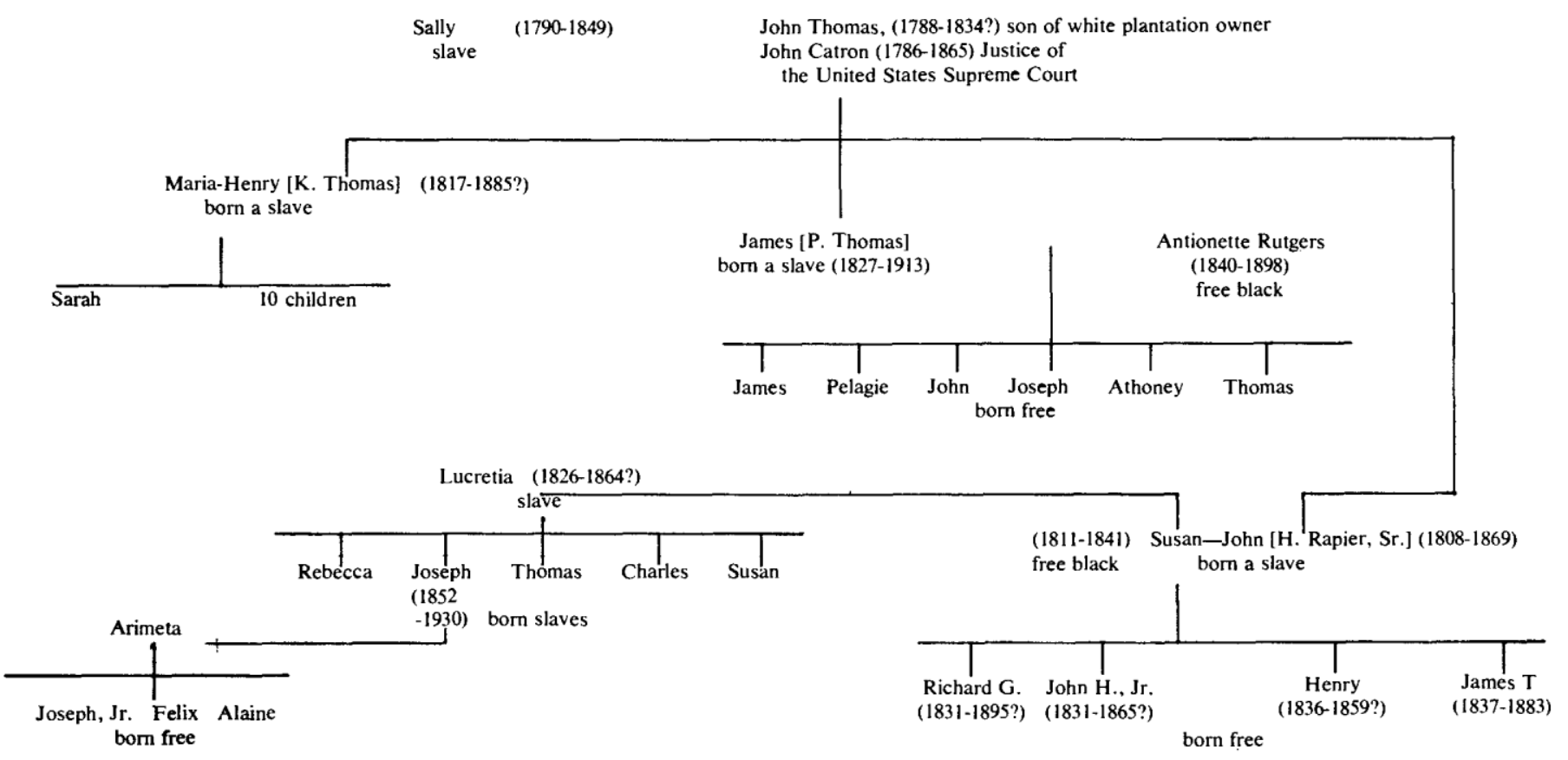

settlement of the Thomas Estate in 1834, "Sally and the two mulatto boys," reverted to one John Martin, an affable young man who wanted to sell a part of his inheritance for a quick profit. Fearing that her children would be sold "down river to Mississippi," Sally urged Henry to escape. Heeding his mother's advice, Henry fled through upper Tennessee and Kentucky but was captured near Louisville and confined to a guard house. He managed to work off his leg-chains one night, however, steal down to the Ohio River, untie a boat, and drift into the current. "The night was cold," Henry wrote afterwards. "I headed the yawl downstream, sculled over the falls and made for the Indiana shore. There I found a man who freed my hands." ${ }^{18}$ Taking the surname Thomas, he travelled to Buffalo, New York, where he opened a barber shop. ${ }^{19}$

Shortly after Henry's escape, Sally went to Ephraim H. Foster, a prominent Tennessee lawyer, and asked for assistance in putting James out of Martin's reach. "Will you talk with him [Martin] and see what he will take for the boy," she asked. "Very well, Aunt Sally," Foster replied, "I will see him and let you know what can be done." A few days later Foster told her that Martin wanted

\footnotetext{
${ }^{17}$ Lauderdale County Probate Records, Wills, Vol. VI (June 3, 1824), p. 117; Acts of the Eleventh Annual Session of the General Assembly of the State of Alabama (Tuscaloosa McGuire, Henry and Walker, 1830), p. 36; Richard Rapier, Auburn, California, to James P. Thomas, December 14, 1877, Rapier Papers, Moorland-Spingarn Collection, Howard University, Washington, D.C., hereafter Rapier Papers.

18 "Thomas Autobiography," chapter 1; "Miscellaneous Notes of James P. Thomas," Moorland-Spingarn Collection, Howard University, Washington, D.C., n.p.; John H. Rapier, Sr., Florence, Alabama, to Henry K. Thomas, Buffalo, New York, February 28, 1843, Rapier Papers; A. M. Simmons, Cincinnati, Ohio, to Henry K. Thomas, Buffalo, New York, May 26, 1836, ibid.; Buffalo City Directory (Buffalo: Horatio N. Walker, Publisher, 1844), p. 213. 19 "Thomas Autobiography," pp. 1-6.
} 
\$400. "I have saved only \$350," Sally explained, but quickly added: "Now if you, Col. Foster, will pay the fifty and make it four hundred, have the bill of sale made to yourself, you can hold James in trust until I return [the] money. I want you to be his protector." Foster agreed and the bargain was sealed. A short time later, she paid off the debt and received a bill of sale, "free papers," for six-year-old James. ${ }^{19}$ Even then, however, he was not free. The law required emancipated Blacks to secure a manumission deed from the county court, and "thereupon immediately leave Tennessee." ${ }^{20}$ Thus, despite having "free papers," James was still legally a slave.

But neither the law nor slavery seemed to curtail his activities. As a young boy, he performed a variety of chores for his mother: keeping salt in the hopper for making soap, cutting wood for the fire place, cleaning up around the house, and delivering clothes to customers. He also enrolled in the Nashville school for Blacks. Thomas recalled sitting on splintery benches, in a drafty oneroom school house and listening to ill-prepared lessons on such basic subjects as "the fundamentals of reading." In addition, he remembered that the school remained open only a few months each year, the pupils, or "scholars," had to pay a very high $\$ 4$ tuition fee, and that free Blacks Rufus Conrad, Daniel Watkins and Samuel Lowery taught at the school from time to time. "But often," he said, "there was no school because there was no teacher." In 1836, for instance, a black teacher, described as "a fine scholar," was taken out by whites and whipped nearly to death. "Tennesseans generally opposed educating blacks," he recalled, "they might want the same as whites." But young James had an intense desire to learn and quickly mastered the basics of mathematics, reading and writing. ${ }^{21}$

Having secured a rudimentary education, James hired out as an apprentice barber. Working with bondsman Frank Parrish, who had earlier established a barber shop on Public Square, he quickly learned the trade. ${ }^{22}$ "James [is] still with Frank Parrish and has the character of a good barber, So

\footnotetext{
${ }^{20}$ Acts Passed at the First and Second Session of the Nineteenth General Assembly of the State of Tennessee (Nashville: Allen Hall and A. S. Heiskel, Printers to the State, 1832), p. 167; Robert William Fogel and Stanley L. Engerman in their statistical study Time on the Cross: The Economics of American Negro Slavery (Boston, 1974) also conclude that the slave family was a viable institution, but they, like most historians concerned with the peculiar institution, emphasize the role and attitudes of whites. They suggest that the Negro family survived for three basic reasons: the desire of planters to promote family stability (to increase the output of contented slaves); the extreme reluctance of owners to break up family units; and the Victorian attitudes among the planting class, which made miscegenation extremely rare, resulting in a miniscule percent of mulattoes in the ante bellum South (7.7 in 1850 and 10.4 in 1860). Besides the impressionistic evidence used by the two cliometricians to support their contentions, the dubious relationship between the extent of sexual exploitation and the percent of mulattoes in the South in a given year (which is itself upon question), and the mis-interpretation of the quantified evidence concerning the break up of families on the New Orleans auction block between 1804-1862 (the authors suggest 84 percent of the sales involved unmarried individuals, but failed to reveal that the slave's familial status was generally not recorded), the greatest weakness of the study is the obvious inadequacy of quantification methods in evaluating the slave family. Statistical evidence does not reveal the feelings of interdependence, unity, and cohesiveness that black family members in bondage felt for one another. Robert William Fogel and Stanley L. Engerman, Time on the Cross: The Economics of American Negro Slavery (Boston, 1974), pp. 126-144.

21 "Thomas Autobiography," chapters 1, 2; "Miscellaneous Notes of James P. Thomas," Moorland-Spingarn Collection, Howard University, Washington, D.C.; James P. Thomas, Nashville, Tennessee, to John H. Rapier, Jr., St. Paul, Minnesota Territory, October 3, 1856.

${ }_{22}$ The Nashville Republican, April 21, 1836; The Nashville Daily Republican Banner, April 9, 1841; Davidson County Probate Records, Minutes, Book E (October 4, 1853), pp. 563-564. Many times, as in this instance, probate
} 
a Gentleman told me," his brother, John Rapier, observed in 1843. "He is well thought of by the Gentlemen. James has manners to please almost anyone who does not let their prejudice go far on account of color." ${ }^{23}$ Two years later James was still with Parrish, earned \$12 a month, and at the same time had begun violin lessons with one Gordan McGowan. "James will make a man of musick I think. He seems to be very fond of it." ${ }^{24}$ Having served a five-year apprenticeship, in 1846, he opened his own barber shop. The nineteen-year-old slave established his shop in the house where he had grown up (and where his mother still operated her cleaning business), at 10 Deaderick Street. The location was ideal. Within a few steps of several banking houses, newspapers, and law firms, as well as the county court house, Market Square, and the Capitol, "the place on Deaderick," he explained, "was convenient to bankers, merchants, lawyers, politicians, and professional men." He counted among his customers six famous Tennesseans: William Carroll, one time governor; E. S. (Squire) Hall, an important businessman; General William Harding, owner of Bellemeade Estate; Ephraim Foster, a Whig political leader; and William G. (Parson) Brownlow, the Civil War governor. ${ }^{25}$ Francis Fogg, the well-known Davidson County lawyer, visited the Thomas shop daily. "He returns to us in the evening," Mrs. Fogg noted approvingly, "with face smooth and curls nicely arranged." 26

While attending to his duties as a barber, James listened attentively to conversations that took place among his customers. "They had time to talk in the barber shop. Nobody seemed in a great hurry. Everything was discussed-social, commercial, political and financial." He remembered conversations about the abolitionists, the advancement of cotton on the Liverpool market, the magnetism and sporting proclivities of Andrew Jackson, plantation acreage along the Mississippi, and fugitive slaves. Once, he recalled being sharply questioned about runaway Blacks. "You have a brother living in Buffalo, New York, I believe," General Harding asked pointedly. "Yes," was the reply. "Well he treated me in a gruff manner. I went to ask him if he knew anything about a boy who ran off from me. I told him I only wanted to see him. I had come to Buffalo for that purpose. I received a very cold and indifferent reply." James could do little but apologize for his brother's "rudeness." Though he usually remained silent when the conversation turned to such controversial issues; at times he ventured an opinion on the slavery question. Once, for example, while shaving a young Virginia lawyer, he defended the Wilmot Proviso, a proposal to prohibit slavery in the newly acquired Mexican territories. "The set back I got caused

court cases included biographical material about Blacks to illustrate their "good character." Davidson County Probate Records, Wills and Inventories, Vol. 16 (November 28, 1854), pp.429-430.

${ }^{23}$ John H. Rapier, Sr., Florence, Alabama, to Henry K. Thomas, Buffalo, New York, February 28, 1843, Rapier Papers.

${ }^{24}$ John H. Rapier, Sr., Florence, Alabama, to Richard Rapier, Buffalo, New York, April 8, 1845, Rapier Papers.

25 "Thomas Autobiography," chapters 1, 2, 3; The Nashville General Business Directory (Nashville: The Daily American Book and Job Printing Office, 1853), 1-20; For the early business and financial activities of E. S. Hall in Nashville, see: John Claybrooke Papers, Manuscript Division, State Library and Archives, Nashville, Tennessee; For the activities of the other whites mentioned, see: Philip Hamer, Tennessee: A History, Vol. I (New York: American Historical Society, 1935), pp. 282, 370, 381, 475; "Leadership in Nashville: Biographical Sketches of 116 of the Most Prominent Citizens in Nashville," Catherine Filcher Avery Papers, Manuscript Division, State Library and Archives, Nashville, Tennessee; "Old Days in Nashville, Tennessee: Reminiscences by Jane Thomas," (no relation to James Thomas), reprints from the Nashville Daily American, 1895-1896 in Jane Thomas Papers, Manuscript Division, State Library and Archives, Nashville, Tennessee; The Officlal Political Manual of the State of Tennessee (Nashville, Tennessee: Marshall and Bruce, 1890), p. 180.

${ }^{26}$ Ellen S. Fogg, Nashville, Tennessee, to E. H. Foster, Louisville, Kentucky, February 15, 1849, Ephraim Foster Papers, Manuscript Division, State Library and Archives, Nashville, Tennessee. 
me to be careful in the future. Among other things he told me I had no right to listen to a gentleman's conversation." ${ }^{27}$ Despite such "set backs," James built up a flourishing business. Charging 25 cents for a haircut, 15 cents for a shave, and $\$ 1$ for occasionally extracting teeth, he operated one of the most prosperous "tonsorial establishments" in Nashville. In the city's first business directory (published in 1853), he advertised in large boldface print: "JAS. THOMAS, BARBER SHOP, 10 Deaderick St." ${ }^{28}$

Meanwhile, Sally's other two children, freedman John H. Rapier and fugitive Henry Thomas, were also prospering as barbers. Rapier opened a shop in Florence, Alabama, soon saved over $\$ 500$, purchased a white frame house on Court Street in the downtown district, and like James, converted the house into a place of business as well as a residence. In 1831, he married Susan, a free Black from Baltimore, Maryland, and in the next decade the couple had four children:

Richard, John Jr., Henry and James. ${ }^{29}$ After his wife's death in childbirth at the age of twentynine, he purchased a sixteen-year-old slave, Lucretia, and between 1848 and 1861, they had five slave children, the youngest named Susan. ${ }^{30}$ During the ante bellum period Rapier acquired real estate holdings in Alabama, the Minnesota Territory, and Canada, purchased valuable railroad stock, and saved $\$ 2000$ in cash. By 1860, he was one of the wealthiest free Blacks in Alabama, with about $\$ 10,000 .^{31}$

Henry Thomas also opened a barber shop. Locating in the basement of Buffalo's elegant hotel Niagara, he too built up a lucrative trade. About 1835, he married a black woman, Maria, and they had eleven children, ten boys and a girl, Sarah. ${ }^{32}$ In 1852, to avoid apprehension by slave catchers (who were encouraged by the 1850 Fugitive Slave Law), he moved to the black community of Buxton, Canada West. With resources he had saved as a barber, he purchased one

\footnotetext{
27 "Thomas Autobiography," chapter 2.

${ }^{28}$ Nashville Business Directory (Nashville: Daily American Book and Job Printing Office, 1853), p. 68.

${ }^{29}$ Richard Rapier, Auburn, California, to James P. Thomas, December 14, 1877, Rapier Papers; In this letter Richard, John Rapier's eldest son, refers to his date and place of birth. In the "Diary and Notes of John H. Rapier, Jr.," March 10, 1857, Rapier Papers; John, Rapier's third son, likewise refers to his birth date; U.S. Census Office, Sixth Census of the United States, "Population Schedules for Lauderdale County, Alabama," Vol. IV, (1840), p. 104; James T. Rapier, Florence, Alabama to John H. Rapier, Jr., St. Paul, Minnesota Territory, September 27, 1858, Rapier Papers; "Thomas Autobiography," p. 73; Alabama State Sentinel, November 25, 1867; The inscription on Susan Rapier's tombstone reads: "Sacred to the memory of Susan Rapier. Born in Baltimore, Md. 25 of December 1811 departed this life at Florence Alabama 10 of March 1841 - also her two infant children Jackson and Alexander-Depart my friends and dry up your tears for I must lie hear [sic] till Christ appears."

${ }^{30}$ U.S. Census Bureau, Sixth Census of the United States, Population Schedules for Lauderdale County, Alabama," Vol. IV, (1840), p. 104; United States Census Bureau, Seventh Census of the United States, Populations Schedules for Lauderdale County, Alabama," Vol. I, (1850), p. 293; United States Census Bureau, Eighth Census of the United States, Vol. VI (1860), p. 39.

${ }^{31}$ John H. Rapier, Sr., Florence, Alabama, to Richard Rapier, Buffalo, New York, April 8, 1845, Rapicr Papers; John H. Rapier, Sr., Florence, Alabama, to John H. Rapier, Jr., St. Paul, Minnesota Territory, Scptember 16, 1857, Rapier Papers; Lauderdale County Probate Records, Wills and Inventories, Vol. B (September 13, 1869), pp. 78-80, Land Deeds, Book II (May 3, 1844), p. 78; Book XVI (August 7, 1858), p. 324; The Florence Gazette, March 5, 1862; Loren Schweninger, "John H. Rapier, Sr.: A Slave and Frcedman in the Antebellum South," Civil War History/Vol. 20, (March 1974), p. 31.

${ }^{32}$ A. M. Simmons, Cincinnati, Ohio, to Henry K. Thomas, Buffalo, New York, May 26, 1836, Rapier Papers; Buffalo City Directory (Buffalo: Horatio N. Walker, Publisher, 1844), p. 213; John H. Rapier, Sr., Florencc, Alabama, to Hcnry K. Thomas, Buffalo. New York, February 28, 1843, Rapier Papers; "Thomas Autobiography," chaptcr 1; Buffalo City Directory (Buffalo: Jewett, Thomas and Company, Commercial Advertiser Office, 1847-48), p. 158.
} 
hundred acres of wilderness land, built a log house, cleared the trees, and put in a crop of corn, wheat and barley. ${ }^{33}$ "The settlement improves slowly, but prospects are good for its success," he noted in 1856. "The lumber mill is making improvements for the neighborhood. Soon the railroad will pass through. The school is flourishing. I have six acres in wheat and 2 in barley." ${ }^{34}$ Thus, using one of the few profitable occupations open to ante bellum Blacks, James, John and Henry were all able to achieve a degree of financial independence.

The members of the slave family were also successful at maintaining close family ties. Though separated by hundreds, even thousands of miles, though forbidden to travel in certain regions, and though denied postal privileges, they kept in close touch. As a slave and also when he was a free Black, John Rapier Sr. frequently visited Nashville. And between 1838 and 1846, he arranged for all four of his children to attend school in the Tennessee capital and to stay with their slave uncle and slave grandmother. "John and James are so [well] pleased with their grandmother [and school], he noted in 1843, "that they do not want to come home, so James writes." ${ }^{35}$ A couple of years later he added: "My two sons that are with mother are well when I last hear[d] from them. I entend to go up to Nashville in the course of ten or twelve days and See them all." On that occasion Rapier confessed that he had not been to Tennessee in nearly a year. "I am extremely anxious to See the family again," he said, promising to deliver a letter from his brother, which had been smuggled into the South from the North. After a visit to the Tennessee capital, he wrote to "Brother Henry": "Mother looks as young as she did 8 years ago and works as hard and hardly takes time to talk to you." Forwarding other family news, he said that "Brother James" was doing extremely well as a barber; and of his sons, he proudly observed that Richard wrote in an excellent hand; Henry wanted to continue his education; James read extremely well "for a little boy of his age [6] and training;" and "John has wrote me two letter and writes very plain for a boy of eight, ... and has as much taste for reading as any child I know off and is very good in arithmetic." ${ }^{36}$ Rapier not only journeyed to Tennessee often, but about once a year, he travelled to New York or Canada. ${ }^{37}$ After one such sojourn, he expressed concern for Brother Henry's future in the North. "I told him to buy [more] land in that country and to pay the taxes. [But] I am fearful that Brother Henry will come to want in [Canada] as I am of the opinion that [it] is poor farming country." ${ }^{38}$ For their parts, Henry and James also expressed a deep concern for the welfare of the slave family. Henry usually concluded his letters with the simple, but significant, line: "All the family is well and wishes to be remembered to you. ${ }^{39}$ And James Thomas wrote: "A letter from your hands [John Rapier Jr.] offers me a great

\footnotetext{
${ }^{33}$ Henry K. Thomas, Buxton, Canada West, to John H. Rapier, Sr., Florcnce, Alabama, October 27, 1856, Rapier Papers; James T. Rapier, Buxton, Canada West, to John H. Rapier, Jr., St. Paul, Minnesota Territory, June 26, 1857, Rapier Papers; "Thomas Autobiography," chapter 1.

${ }^{34}$ Henry K. Thomas, Buxton, Canada West, to John H. Rapier, Sr., Florence, Alabama, October 27, 1856, Rapier Papers.

${ }^{35}$ John H. Rapier, Sr., Florence, Alabama, to Henry K. Thomas, Buffalo, New York, February 28, 1843, Rapier Papers.

${ }^{36}$ John H. Rapier, Sr., Florence, Alabama, to Richard Rapier, Buffalo, New York, April 8, 1845, Rapier Papers.

37 "The Autobiography of William King," (1890), p. 255, King Papers, Public Archives of Canada, Ottawa, Ontario; King, who founded Buxton, reminisced about Rapier's frequent visits to Toronto and Buxton during the 1850's; John H. Rapier, Sr., Florence, Alabama, to John H. Rapier, Jr., Minnesota Territory, September 16, 1857, Rapier Papers.

38 "John H. Rapier, Sr., Florence, Alabama, to John H. Rapier, Jr., Minnesota Territory, September 15, 1856, Rapier Papers.

39 Henry K. Thomas, Buxton, Canada West, to John H. Rapier, Sr., October 27, 1856, Rapier Papers; March 13, 1857; Henry's only daughter Sarah wrote to John Rapier, Jr.: "Through Papa and James I would like to give you
} 
deal of pleasure to say nothing of the family news it imparts." ${ }^{40}$ It seems that separation, an inherent part of the institution of slavery, had little effect on the spiritual unity of the slave family.

There was also a solidarity among the members of the Rapier family. Deeply concerned about the welfare of his children, John Rapier offered them advice on everything from economic matters to questions of morality: "Settle your debts," "Save your money," "Stay away from liquor," he admonished "The Four Boys." "Stick closer to work and Say nothing and do nothing but what is right and you will do well my sons." ${ }^{41}$ In 1845 he wrote Richard, who was attending school in Buffalo and living with Henry Thomas: "Study your books so I can hold you up as an example to your lettle Brothers. You are blessed if you will look at your situation. You have kind relations who are anctious to see you grow up an ornament to society." 42 Perhaps the best expression of the spiritual unity of the Rapier family was written by James Thomas Rapier, James P. Thomas's namesake and one of Sally's twenty-six grandchildren. Also living with fugitive Henry Thomas, and attending school in Buxton, he wrote:

In our boyhood ... all four of us boys were together. We all breathed as one. [Now] we are scattered abroad on the face of the Earth. Do you ever expect to see us all together again? I do not. Just look where we are ... John in [Minnesota]. Myself in the north. Henry and Dick in California. Father in Alabama. Did you ever think how small our family is? ${ }^{43}$

Among the Rapiers, as well as the Thomases, there was an almost religious devotion to the institution of the family.

The ability of the slave family to remain so close seems all the more remarkable in the face of the legal restrictions placed on Blacks. Statutes forbade a free Black from either visiting with slaves, or travelling from one state to another, both on penalty of being sold into slavery. Laws prohibited slaves from owning personal property, renting real estate, earning money, or securing an education. "No person shall hire to any slave," one Tennessee code pronounced, "the time of said slave." ${ }^{44}$ Lawmakers prescribed a ten year prison sentence to anyone helping a slave to escape, forging a pass for a slave, harboring a runaway or inciting a Black to defy a white; and

some news ... Mama and Papa are well as is the rest of the family and they sent their compliments. We shall all feel very much pleased if you make a visit to this place." Sarah Thomas, Buxton, Canada West, to John H. Rapier, Jr., Minnesota Territory, March 10, 1857, Rapier Papers.

${ }^{40}$ James P. Thomas, St. Louis, Missouri, to John H. Rapier, Jr., Minnesota Territory, June 17, 1858, Rapier Papers.

${ }^{41}$ John H. Rapier, Sr., Florence, Alabama to John H. Rapier, Jr., Minnesota Territory, September 15, 1856, Rapier Papers; John H. Rapier, Sr., Florence, Alabama to John H. Rapier, Jr., Benton County, Minnesota Territory, December 13, 1856, Rapier Papers.

${ }^{42}$ John H. Rapier, Sr., Florence, Alabama, to Richard Rapier, Buffalo, New York, April 8, 1845, Rapier Papers.

${ }^{43}$ James Rapier, Buxton, Canada West to John H. Rapier, Jr., Little Falls, Minnesota Territory, January 27, 1857, Rapier Papers.

${ }^{44}$ Acts Passed at the First Session of the Fourteenth General Assembly of the State of Tennessee (Knoxville: Heiskell and Brown, Public Printers to the State, 1821), p. 34; Acts Passed at the Second Session of the Fourteenth General Assembly of the State of Tennessee (Knoxville: Heiskell and Brown, Printers to the State, 1822), p. 22; Acts Passed at the First Session of the Fifteenth General Assembly of the State of Tennessee (Murfreesborough: J. Norvell and G. A. and A. C. Sablett, 1823), p. 76; Acts Passed at the Extra Session of the Sixteenth General Assembly of the State of Tennessee (Knoxville: Heiskell and Brown, 1927), 31-33; Acts Passed at the First and Second Session of the Nineteenth General Assembly of the State of Tennessee (Nashville: Allen A. Hall and A. S. Heiskell, Printers to the State, 1932), pp. 165-170. 
laid down the death penalty for Blacks convicted of assaulting or molesting a white woman, maliciously setting fire to a barn, preparing any poison, or conspiring to revolt. "A ring leader or Chief Instigator of any plot to rebel or murder any white," one law stated, "may be lawfully killed [on sight], if it is not practicable, otherwise, to arrest and secure him." ${ }^{45}$ Nashville ordinances required free Blacks to pay a capitation (head) tax of $\$ 1$ or $\$ 2$, register at the court house, and "carry free papers on their person at all times." Blacks without such papers were to be treated as slaves. Moreover, Negroes were not permitted to walk the streets after dark, enter tippling houses, make weird noises, or gather within the city limits for any purpose, except public worship, and Blacks attending church were to be supervised by whites. ${ }^{46}$

But the slave family disregarded the elaborate code governing Blacks. Sally hired out, earned money, rented a house, and operated a business. "Mother lived so long at the corner of Deaderick and Cherry Streets," James Thomas remarked later, "that the people of Nashville thought she [was free] and owned the property." She moved about the city with little hindrance, boarded her grandchildren as they attended school, and secretly advised Henry to escape to the North. ${ }^{47}$ In a similar manner James Thomas hired out, earned money and established a business. He eventually accumulated a large amount of personal property - furniture, mirrors, clothes, and about $\$ 1000$ in cash, and while still a slave, became the manager of one of the largest barbering establishments in Nashville. He travelled to various parts of the city without a pass, entertained free Blacks in his home, and attended black church meetings. At one such gathering he recalled the black congregation, mostly slaves, singing until 12 o'clock at night. "The owners," he wrote, "seemed to care very little how much religion their servants got. They seemed to encourage it." ${ }^{48}$ In much the same way John Rapier and Henry Thomas acquired personal property, hired out,

\footnotetext{
${ }^{45}$ Private Acts Passed at the Called Session of the Nineteenth General Assembly of the State of Tennessee (Nashville: Allen A. Hall and F. S. Heiskell, Printers, 1832), pp. 5, 6; Public Acts Passed at the First Session of the Twentieth General Assembly of the State of Tennessee (Nashville: Allen A. Hall and F. S. Heiskell, Printers to the State, 1833), pp. 2, 3, 75, 76, 14, 87, 94, 99, 100, 215, 216; Public Acts Passed at the First Session of the Twentyfirst General Assembly of the State of Tennessee (Nashville: S. Nye and Co., Printers, 1836), pp. 92, 145, 146, 167; Acts Passed at the First Session of the Twenty-third General Assembly of the State of Tennessee (Nashville: J. Geo. Harris, Printer to the State, 1840), pp. 82, 83; Acts Passed by the First Session of the Twenty-fourth General Assembly of the State of Tennessee (Murfreesborough: Cameron and Company, Printers to the State, 1842), pp. 229, 230; Acts of the State of Tennessee Passed at the First Session of the Twenty-sixth General Assembly (Knoxville: James C. Moses, 1846), p. 278; Acts of the State of Tennessee Passed at the First Session of the Twenty-eighth General Assembly (Nashville: McKennie and Watterson, Printers to the State, 1850), p. 30; Acts of the State of Tennessee Passed at the First Session of the Twenty-eighth General Assembly (Nashville: McKennie and Watterson, Printers to the State, 1850), p. 304; Acts Passed at the First Session of the Twenty-ninth General Assembly (Nashville: McKennie Printers, 1852), pp. 120, 521; Acts of the State of Tennessee Passed at the First Session of the Thirtieth General Assembly (Nashville: McKennie and Brown, Book and Job Printers, 1854), pp. 121, 122, 157; Acts of the State of Tennessee Passed at the First Session of the Thirty-first General Assembly (Nashville: Printed by G. C. Torbett and Company, 1856), pp. 71, 77; William Imes, "The Legal Status of Free Negroes and Slaves in Tennessee," Journal of Negro History, IV (July 1919), pp. 260, 261.

${ }^{46}$ Revised Laws of the City of Nashville (Nashville: Union and American Steam Press, 1854), pp. 147, 154-58; Revised Laws of the City of Nashville (Nashville: Harvey M. Watterson Printers, 1850), pp. 124-26; Acts Passed at the First Session of the Twenty-fifth General Assembly of the State of Tennessee (Nashville: L. Gifford and E. G. Eastman, Printers, 1844), p. 18.

47 "'Thomas Autobiography," chapter I.

${ }^{48}$ lbid.; "Miscellaneous Notes of James P. Thomas," Moorland-Spingarn Collection, Howard University, Washington, D.C., n.d.; James P. Thomas, Louisville, Kentucky, to John H. Rapier, Jr., St. Paul, Minnesota Territory, March 1, 1856, Rapier Papers; James P. Thomas, Nashville, Tennessee, to John H. Rapier, Jr., Minnesota Territory, October 3, 1856, Rapier Papers.
} 
earned as much as \$50 a month, and, despite the laws against the movement of Blacks, travelled throughout the South, North, and Canada. Rapier even assisted a slave, Sam Ragland, to escape on one occasion. ${ }^{49}$ In short, the slave family was not in the least constrained by the restrictive black codes.

Sally's dream that all of her children secure their freedom finally came true in 1851, when her youngest son, James, asked Ephraim Foster to present a manumission petition to the Davidson County court. The slave and his master appeared at the courthouse in Nashville on March 6. "James has always maintained an exemplary character," Foster told the nine judge panel hearing the case. "He has been industrious, honest, moral, humble, polite and had conducted himself as to gain the confidence and respect of whites. He is a man of great worth in his place." The testimony of such an eminent Tennessean swayed the magistrates and, after a short deliberation, they ordered "the slave James, otherwise called James [P.] Thomas, emancipated and forever set free." Thomas now addressed the court himself. He requested immunity from the 1831 law requiring manumitted Blacks to leave Tennessee. "I have deported myself in a manner requiring the confidence of whites. I have always earned a good living. I would be greatly damaged having to Start anew in some Strange Country." The judges, after receiving the required $\$ 500$ good behavior bond, granted the immunity. James P. Thomas thus became the first black man in the county, perhaps the state, under the stringent emigration law of 1831, to gain legally both freedom and residency. ${ }^{50}$

A short time before James gained his freedom, however, Sally died of cholera. ${ }^{51}$ A woman of great drive and dedication, she had devoted her life to freeing her children. She had hired out, started a business, and gladly put up her life savings to purchase "free papers" for James. She had also assisted Henry in his quest for freedom. Due in part to her unwavering efforts, the slaves John H. Rapier, Sr., Henry K. Thomas, and James P. Thomas, all gained free status before the Civil War. In addition, the Thomases and Rapiers all found great strength in the slave family. Members of these families were quite successful: John entered politics during Reconstruction; Henry farmed hundreds of acres in Canada; and James acquired property in St. Louis valued at $\$ 250,000 ;{ }^{52}$ while Sarah Thomas became a school teacher, James T. Rapier a Congressman, and John Rapier, Jr. a surgeon, stemmed from the security they found in the slave family. ${ }^{53}$ It seems that for the black slave Sally, sexual exploitation, miscegenation, separation, and legal restrictions - the very forces designed, in part, to destroy the black family — gave impetus, not to disintegration and disunity, but to an extraordinary feeling of family loyalty, unity, and love. For

\footnotetext{
${ }^{49}$ Loren Schweninger, "John H. Rapier, Sr.: A Slave and Freedman in the Antebellum South," Vol. 20, Civil War History (March 1974), passim.

50 "Thomas Autobiography," pp. 1-8; Davidson County Probate Records, Minute Book E (March 6, 1851), pp. 134, 135.

51 "Thomas Autobiography," p. 1; James Thomas said that his mother died in a cholera epidemic in 1850, but it was probably in the spring of 1849, when hundreds of Nashvillians died from the dreaded disease.

52 "The Florence Journal, September 18, 1869; Assessors Records, City of St. Louis, Plate 1874-1876, number B65, Blk 300, 301, 691; Assessors Records, City of St. Louis, Tax Books for 1871, Book 17 (1871), pp. 20-21; Probate Records of the City of St. Louis, Warranty Deeds, Book 452 (August 13, 1872), pp. 470, 471; "Autobiography of William King," pp. 355-360.

53 James T. Rapier, Montgomery, Alabama, to William King, Buxton, Ontario, July 7, 1872, King Papers; Loren Schweninger "James Rapier and Reconstruction," (PH.D. dissertation, Chicago, 1972), passim.
} 
Sally, her children, and her grandchildren, the slave family was indeed "a refuge from the rigors of slavery." 